\title{
Project and Production Management in the Construction Industry
}

\author{
Chien-Ho Ko \\ Editor-in-Chief \\ Editorial \\ Available online June 25, 2012
}

In this issue, the Journal of Engineering, Project, and Production Management (EPPM-Journal) presents five original research papers related to project and production management in the construction industry from authors in Africa, Asia, and Europe.

The construction industry is characterized by complexity, uncertainty, capital, and labor-intensiveness (Ko and Cheng, 2007), making appropriate project and production management a key success factor (Halpin and Senior, 2010; Santos et al., 2002). Project management is primarily applied to enhance project performance (Ko, 2011), while production management is used to enhance material supply or through treating the construction project as a production process (Ballard, 2000).

Two of the current articles fall under the topic of Project Management. In the first, Ibrahim et al. propose a framework to identify appropriate frame rates for the observation of construction operations from time-lapse movies, which are frequently used to observe construction productivity (Abeid and Arditi, 2002). Such recordings could be helpful in reducing the costs of construction productivity observation. In the second paper, Martin Dada investigates conflicts in organizations that detract from the achievement of project objectives, recommending that conscious teambuilding efforts be made to reduce the impact of conflicts on project performance.

In Production Management, Lennartsson and Björnfot use the Systematic Production Analysis (SPA) approach to analyze production loss, i.e. scrap or downtime. They present a model which can reduce scrap without increasing the total work costs and, in turn, improve production control.

Two papers fall under the topic of Project and Production Management. The first, by Bo Terje Kalsaas, was selected from the 19th Annual Conference of the International Group for Lean Construction, and its inclusion was made possible through the assistance of John Rooke, the conference's Technical Chair. Kalsaas attempts to analyze the Last Planner System (LPS) from the perspective of learning processes for knowledge development. The LPS proposed by Ballard (2000) is widely used in Lean Construction. Kalsaas's article develops three research questions to understand the LPS, arguing that an understanding of the LPS grounded in learning theory can improve the likelihood of successful implementation.

The second paper, by Ko and Chen, hypothesizes that finishing production later relative to required delivery dates can reduce inventory and protect fabricators against the impact of demand variability. A Time Buffer Evaluation Model (TBEM) consisting of two stages is developed to promptly deliver products while maintaining a smaller inventory.

In conclusion, this issue presents approaches to Project and Production Management in the construction industry covering topics including construction operations observation, project conflict analysis, production resource management, production control, and precast fabrication planning. We hope researchers and practitioners find this issue to be of interest and practical use.

\section{References}

Abeid, J. and Arditi, D. (2002). Time-lapse digital photography applied to project management. Journal of Construction Engineering and Management, ASCE, 128(6), 530-535.

Ballard, G. (2000). The Last Planner System of Production Control, $P h D$ Thesis, University of Birmingham, UK.

Halpin, D. W. and Senior, B. A. (2010). Construction Management. John Wiley \& Sons, NY, NY.

Ko, C. H. and Cheng, M. Y. (2007). Dynamic prediction of project success using artificial intelligence. Journal of Construction Engineering and Management, ASCE, 133(4), 316-324.

Ko, C. H. (2011). Integration of Engineering, Project, and Production Management. Journal of Engineering, Project, and Production Management, 1(1), 1-2.

Santos, A., Powell, J. A., and Sarshar, M. (2002). Evolution of management theory: the case of production management in construction. Management Decision, 40(8), 788-796. 